\author{
Довгань Наталія Олександрівна \\ кандидат психологічних наук, докторант, \\ Інститут соціальної та політичної психології НАПН України, \\ м. Київ, Україна \\ ORCID ID 0000-0001-6150-5211 \\ 1511ndovgan@gmail.com
}

\title{
ПОКОЛІННІ ЕСПЕКТАЦІЇ В СОЦІАЛЬНО-ПСИХОЛОГІЧНОМУ ПОЛІ СПІВІСНУВАННЯ
}

\begin{abstract}
Для вибудовування теоретичних положень концепції фігуративних соціокультурних зв'язків поколінь конкретизовано базові категорії аналізу і розкриття особливостей характеристик соціальнопсихологічного простору поколінь. Завданням наукового дослідження стало розроблення та обгрунтування теоретичних засад пізнання поколінних еспектацій у соціально-психологічному полі співіснування. Акцентовано вплив міжпоколінних психологічних дистанцій, соціальної історичної ситуації, соціокультурного виміру на утворення форм проявів еспектацій. Представлено поколінні соціальні позиції (ентелехії), дії-практики (габітуалізовані) і образи, диспозиції (габітуси) як складові міжпоколінних еспектацій. У контексті поколінного дослідження ентелехію (неологізм Арістотеля) використано як категорію відображення соціальних позицій. Представлено дії-практики, перетворені у звички, стереотипи реагування як габітуалізовані позиції поколінь - особливості прояву еспектацій. Обгрунтовано використання поняття “габітус" (1) як породження ментальності - продукт спільнопоколінної психічної діяльності, що реалізується в динамічному вибудовуванні досвіду і смислів; (2) як схеми отримання, породження, об'єднання, оцінювання, класифікації і використання інформації; (3) як диспозиційних рухів вибудовування оновлених форм фігурацій. У теоретичному конструюванні міжпоколінних еспектацій конкретизовано поняття поколінного інституту як феномену, що закріплює новоутворені практики поколінь, та інституалізації як форми соціальних взаємодій щодо встановлення можливих порядків, відносин у межах поколінних норм, правил, моралі. Таким чином на етапі розкриття характеристик соціально-психологічного простору поколінь було продовжено науковий пошук шляхів пізнання особливостей міжпоколінних відносин, взаємних очікувань поколінь Дітей, Батьків, Прабатьків.

Ключові слова: поколінні еспектації; соціальні позиції; ентелехії; габітуалізовані дії-практики; диспозиції; габітуси; поколінний інститут; інституалізація.
\end{abstract}

\section{GENERATIONAL EXPECTATIONS IN THE SOCIAL-PSYCHOLOGICAL SPACE OF COEXISTENCE}

\author{
Nataliia O. Dovhan \\ Ph. D. in Psychology, Doctoral Student, \\ Institute for Social and Political Psychology, \\ National Academy of Educational Sciences of Ukraine, \\ Kyiv, Ukraine \\ ORCID ID 0000-0001-6150-5211 \\ 1511ndovgan@gmail.com
}

\begin{abstract}
The basic categories for analysis and understanding of characteristics of the generational socialpsychological space are specified with the aim to specify theoretical provisions of the concept of figural socialcultural relations of generations. The research goal was to develop and substantiate the theoretical foundation for cognition of generational expectations in the social-psychological space of coexistence. It is highlighted the influence of inter-generational psychological distances, social historical situation, and socio-cultural dimension on formation of certain types of expectations. There are represented the generational social positions (entelechy), actions-practices (habituated), and images, dispositions (habitus) as components of inter-generational expectations. In the context of the research on generations the entelechy (Aristotle's neologism) is used as a category which reflects social positions. There are presented the actions-practices which are transformed into habits, reactive stereotypes as habituated positions of generations - manifestations of expectations' specificity. It is substantiated the use of the habitus concept (1) as a mentality outcome - the product of common generational mental activities which are fulfilled in dynamic constructing of experience and meanings; (2) as the schemes for
\end{abstract}


information' obtaining, emanation, combining, evaluating, classifying and using; (3) as the dispositional movements for construction of new figurations. In the theoretical constructing of inter-generational expectations it is specificated the generational institution concept as a phenomenon which fixes the newly created practices of generations; and the institutionalization concept as a form of social interactions in order to establish a possible order, relations within the limits of generational norms, rules, and morality. Thus, on the stage of determining the characteristics of social-psychological space of generations it is continued the scientific search for the ways of cognition of the peculiarities of inter-generation relations, mutual expectations of the generations of Children, Parents, and Grand-Parents.

Key words: generational expectations; social positions; entelechy; habituated actions-practices; dispositions; habitus; generational institute; institutionalization

Постановка проблеми. Соціальна природа реальності не функціонує за стабільним планом розвитку потомків під впливом досвіду пращурів, адже в суспільних зв'язках ефект емерджентності у взаємодіях акторів виштовхує уявну “сталість" 3 реалій існування, заміщує ії процесами перепристосування, безперервними рухами виникнення, змін, розчинення (недієвих) формул взаємодій між поколіннями як соціальними явищами. У такому нестабільному полі співіснування сценарії взаємодій, що утворюються і реалізуються за умовно конвеційними правилами суспільних еспектацій, природно, руйнуються неузгодженістю взаємної відповідності міжпоколінних еспектацій. Відмінність соціальних очікувань, опосередкована різними поколінними культурами повсякденної реальності, соціальними позиціями, дисинхронністю конструювання культурних кодів, які висвічують засоби і способи трансляції поколінних інтенцій, стає перепоною для взаємодій та ускладнює міжпоколінні відносини. Останнє є “довічною” проблемою міжпоколінної взаємодії, підтверджуючи необхідність вибудовування теоретичного підгрунтя для відповідей на питання про шляхи конструювання міжпоколінних еспектацій і їх прояв у соціально-психологічному полі співіснування поколінь.

Аналіз останніх досліджень і публікацій, виокремлення нерозв'язаних частин загальної проблеми. Аналіз еспектацій як мотиваційних складників, причин залежності відносин людей від переваг, бажань, спрямувань став невід'ємним компонентом наукових досліджень XIX-XX століть. Питання теоретичних та практичних аспектів соціальних очікувань порушували у своїх роботах Дж. Аткінсон, В. Врум, Р. Лайкерт, Е. Лоулер, Е. Мейо, Л. Портер, Ф. Ретлісбергер, М. Фоллетт та ін. Але, незважаючи на чималу кількість опублікованих наукових праць, проблема розбіжностей в очікуваннях, вічна і незмінна, залишається відкритим питанням, актуальним на соціально-історичних просторах для різних станів розвитку суспільства, у періоди громадянського благополуччя та епохальних потрясінь, в ідеологічному трансформуванні соціальних устоїв. Саме це є підставою для продовження наукового пошуку з проблематики взаємних очікувань у відносинах поколінь Дітей, Батьків, Прабатьків.

Для вибудовування теоретичних положень концепції фігуративних соціокультурних зв'язків поколінь, тобто трактування процесів передавання інформації у відносно стійких соціальних відносинах, які здійснюються в культурних вимірах конкретного часу, необхідно конкретизувати базові категорії аналізу і розкрити особливості характеристик соціально-психологічного простору поколінь, що опосередковують конструювання соціокультурної взаємодії.

Метою статті стало обгрунтування структури поколінних еспектацій у соціальнопсихологічному полі співіснування, що дає змогу визначити психологічні феномени здійснення взаємодії між поколіннями.

Виклад основного матеріалу дослідження. На основі результатів теоретико-методологічного аналізу наукових досліджень соціально-психологічний простір представлено як фрагмент соціальної реальності, що є витвором поколінних акторів. Він складається із соціальних динамічних полів підпросторів поколінь Дітей, Батьків, Прабатьків, що існують за історично-актуальними соціокультурними вимірами, є відображенням “отриманого у спадок” досвіду, реалій і можливих соціальних перспектив. 3 огляду на те, що в динамічних полях покоління презентують різні позиції, відмінні за силою впливів і становищем у суспільстві, для конкретизації поколінних проявів було виокремлено характеристики соціально-психологічного простору поколінь, що визначають особливості конструювання соціокультурної взаємодії: по-перше, соціальні смислові одиниці, що продукуються поколіннями; по-друге, групові еспектації як соціальні очікування; по-третє, поколінні капітали/ресурси задоволення інтересів поколінних акторів у поколінних зв'язках; по-четверте, культурну пам'ять як основу конструювання соціокультурної взаємодії, що пов'язує покоління в 
конструкції наскрізного поколінного ланцюга, розкриває першоджерела психології поколінь у соціальній, культурній, історичній площині.

Щоб визначити психологічні феномени здійснення взаємодії між поколіннями й отримати відповідь на запитання “Що оформлює соціальну поведінку поколінь?”, тобто “Що координує процеси передавання інформації між поколіннями і чому змінюються сценарії взаємодії?”, вектор аналізу було розгорнуто на динамічне поле співіснування поколінь як культурну основу ментальності, оформлену в результаті мережевої акультурації. Динамічне поле співіснування покоління в причетності до “інших" культур проявляє себе у відмінних - “інших" - способах прочитання реальності, а у формуванні конфігурацій психологічних проявів настановлень, уявлень, цілей, інтенцій, ідеології, диспозицій, практик поколінь співвідноситься з розвитком суспільства, історичними ситуаціями, культурними вимірами. Такий ракурс аналізу дав змогу об'єднати соціально-психологічні особливості акторів у єдину структуру очікувань.

Зважаючи на те, що динамічне поле покоління не існує окремо, його вбудовування в наскрізний ланцюг поколінних полів було означено як залежне від актуальних фігуративних форм взаємодій та очікувань акторів. Очікувань, які, за R. J. Rummel (1975), визначають наслідки поведінки, поглинають й утворюють соціокультурне середовище, які є фундаментальними принципами відносин, у яких відчуття, враження, необхідні ролі, можливості і практики взаємодій результують соціокультурні очікування і волевиявлення суб'єктів.

3 огляду на це було зроблено припущення, що на вибудовування соціальної реальності значний вплив справляють конструкти поколінних еспектацій - тобто змістове наповнення їхніх структурних компонентів визначає ті чи інші шляхи інтеграції актора в суспільство, пропонує безліч сценаріїв досягнення цілей, задоволення поколінних запитів. Саме тому динамічне поле покоління не можна розглядати окремо, але лише в сукупності соціальних відносин, що далі, у результаті порівняльного аналізу поколінних еспектацій, дає підстави для наступного етапу дослідження взаємодії поколінь у суспільстві (1) як потоці нескінченних подій "різної швидкості, інтенсивності, ритму і темпу"; (2) непостійних зв'язків - об'єднання і дистанціювання поколінь; (3) безлічі поколінь, “м'якого”, нестатичного поля взаємовідносин “прихильностей, залежностей, обмінів"; (4) як міжпоколінному полі “розширення і згортання" відносин (Штомпка, 1996, с. 22). У зв'язку з цим можемо звернутися до уявлень про існування психологічної міжпоколінної дистанції як прояву функціонування динамічного поля покоління в перетинах міжпоколінних еспектацій i, відповідно, проаналізувати впливи різних дистанцій на процес соціокультурної взаємодії поколінь. Адже, як зазначає R. J. Rummel, силою, що керує взаємодіями, є психологічна дистанція: від А до Б і В, від покоління Дітей до Батьків і Прабатьків. А історична реальність, по-перше, диктує поведінкові можливості, тобто діапазон потенційної поведінки у взаємодіях; обирає “транспортні засоби" надання/констатування значень (конвенційних меж) для інших (поколінь), і по-друге, визначає соціокультурне становище опонентів, яке й коректує сценарії можливих взаємодій у соціокультурному контексті (Rummel, 1975).

Тому можна зробити припущення, що утворення міжпоколінних психологічних дистанцій $є$ результатом проявів складових еспектацій: ентелехій, соціальних практик, габітусу - того, що перетворює конвенційно умовне в очікуване і реальне. Еспектацій, які за особливостями використання в контексті дослідження (1) виступають латентами, що, відповідно, опосередковують результат; (2) представляють усвідомлення, передбачення і розуміння реакцій інших акторів на особливості програвання ролей у “сценарії розвитку подій героями соціального театру”.

Однак те, як саме очікування проявляються в соціально-психологічному просторі і що зумовлює виникнення важелів соціальної поведінки, вимагає подальшого пошуку (рис.).

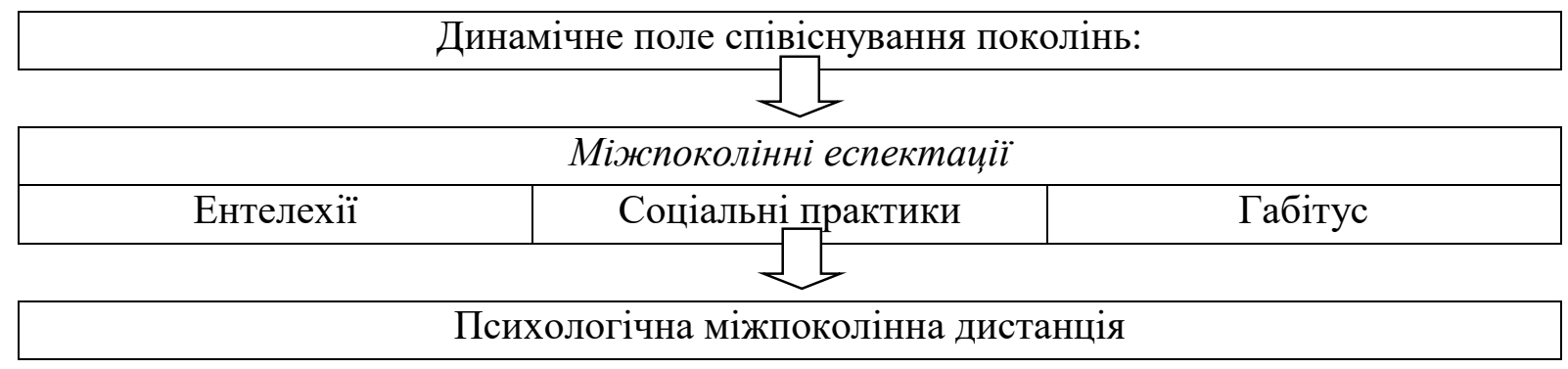

Рис. Модель включення міжпоколінних еспектацій 
У більш детальному огляді міжпоколінних еспектацій у ролі категорії, яка відбиває оформлені поколінні позиції, було використано термін ентелехії (введений Арістотелем) - як внутрішньої сили, що потенційно містить у собі мету й остаточний результат. Але, слід зазначити, якщо, апріорі, психологія поколінь розгортається в історичному часі існуючих ідей і принципів, у яких безперервний потік енергій, спрямованих на втілення, проходить через часову мінливість, то треба враховувати, що саме існуючі соціальні основи відносин стають лакмусом прояву психології мереж поколінь Дітей, Батьків, Прабатьків і артикуляції їхніх неповторних форм соціальних позицій - ентелехій. За ними індивіди існують у соціумі, об'єднуються родовими і фігуративними зв'язками; вибудовують поколінну орієнтацію в просторі. Такі процеси утворення ентелехій відбуваються всюди, де матерія, фізична або духовна, набуває вигляду і форми, де потенція стає втіленою реальністю, а загальне оприявнюється в індивідуальності, де відбувається реалізація ідей, принципів, загальних властивостей. Тому у вибудовуванні різноманіття форм відносин та інтерпретацій реальності в соціокультурному часі покоління саме ентелехї як комплексний показник прояву соціальнопсихологічних особливостей найбільш вдало, на наш погляд, об'єднують переплетені мінливі імпульси покоління: означують спрямованість до реалізації потенціалів, можливостей, утворення смислового наповнення реальності, що реалізується в соціальних позиціях, тобто настановленнях, цілях, уявленнях (Аристотель, 1976; Гуссерль, 2004; Данченко; Кнабе, 1993; 2007).

Необхідно враховувати, що в сучасному світі протягом життя ентелехії поколінь перебувають у безперервних змінах, у стані адаптації і модифікації традиційних (спадкових) моделей досвіду, мислення і вираження. І хоча патерни сприймання, стигматизація та ідентифікація “інших” у групових контекстах обмежені, з одного боку, агентно (активним) потенціалом учасників, з другого боку структурою і культурою навколишнього середовища, за визначенням П. Штомпки, у соціальнопсихологічному полі співіснування вони набувають поступового оформлення.

Нагадаємо, що, згідно з нашим припущенням, поколінні ентелехії, соціальні практики й габітуси вибудовують і реалізують загальні часові міжпоколінні еспектації в контекстах соціальноісторичних ситуацій (Кнабе, 2007; Штомпка, 2009, с. 4; Англо-русский словар..., 2011). Але постає ще одне питання щодо шляхів “виходу”, тобто вивільнення акторів 3 рамок традицій і соціальних детермінант, дієвих у Батьків, Прабатьків, їхньої поступової інституалізації, необхідної для закріплення оновлених соціокультурних вимірів. Адже соціокультурна типізація практик, що являють собою інститут, їх перетворення у звички в поколінному просторі, є природною і зрозумілою для всіх представників поколінної групи (Бергер, \& Лукман, 1995). I саме тому габітус поколінь i габітуалізовані соціальні практики нами обрано як важливі інструменти аналізу особливостей прояву еспектацій у соціально-психологічному просторі.

Тому для подальшого аналізу складових еспектацій поколінь необхідно зупинитися на трактуванні поняття інституту (і саме поколінного інституту), що в роботі буде представлено не статичним феноменом, а процесом закріплення звичаїв, порядків, вибудуваних частиною суспільства (конкретним поколінням). При цьому, якщо інституалізація форм соціальних взаємодій у ментальній площині буде означена як така, що задає встановлення можливих у часовому історичному контексті порядків життєдіяльності; формування звичаїв і традицій; відтворює дієві моделі відносин, їхні форми в межах “умовних" норм, правил, моралі, то інституm постає як процес перетворення у звички поколінних практик, утворених упродовж поколінного життя. Підгрунтям означених понять стали погляди A. Giddens (12989), згідно з якими під “інституалізованими” формами соціальної поведінки малися на увазі форми свідомості і дій, що повторюються, відтворюються суспільством у тривалій просторово-часовій перспективі. Адже в поколінному контексті, зрозуміло, кожне нове покоління буде оновлювати норми і правила міжсуб'єктних взаємодій, опрацьовувати i, отже, утворювати умовно стійкі в часі форми фігурацій, що відповідають соціальним ситуаціям, мати прояв у часі i просторі, транслювати поколінні смисли внутрішньо- і міжпоколінного поля співіснування. При цьому безпосередні комунікаційні контакти не стають обов'язковою умовою вибудовування і трансляції моделей фігуративних зв'язків, адже роль конструктів поколінних інститутів будуть виконувати соціокультурні виміри, дієві в різних комунікаційних системах. У такому контексті покоління можна вважати суспільною матрицею утворення інститутів габітуалізованих зв'язків, типові поколінні моделі соціальних практик - конструктами інститутів соціальних відносин, а суспільство - полем утворення поколінної реальності (Веблен, 1984; Гидденс, 1994; 2005; Giddens, 1989; Бергер, 1995). 
Отже, якщо вважати “головними засобами організації життя ті, що люди утворюють у процесі взаємодій одне з одним і за допомогою яких зберігається спадкоємність поколінь” (A. Giddens), то завдяки виведенню теоретичного визначення сутності соціальних інститутів із фізичної термінології (характерної для H. Spencer, É. Durkheim, M. Weber, N. Smelser та ін.) поколінні мережі можуть бути проаналізовані в соціокультурній площині суспільства - сукупності міжпоколінних інституалізованих форм взаємодій, де ключові позиції інтегрування індивідів у покоління будуть віддані соціокультурним вимірам (Giddens, 1989, p. 118). Адже в основі моделей взаємодії поколінних мереж лежить відновлення засвоєних форм зв'язків як культурних патернів, символічного наповнення відносин, культурних аспектів поведінки (що Т. Parsons називає діями). У такому ракурсі габітуалізація практик поколінь буде підтвердженням: а) синтезу окремих динамічних полів у співіснуванні; б) культурних поколінних нашарувань; в) утворення в результаті стереотипних (тобто звичних) зразків поведінки; г) вибудовування меж приймання "іншого”, ступенів толерантності до різновидів можливого (“образів” опонентів-сучасників); д) означення, що є “природним” у варіаціях щодо доповнення поколінної реальності (Парсонс, 2008, с. 38-71).

Цей синтез культур соціальних практик поколінь і буде встановленням і закріпленням культурного оновлення в образі габітусу поколінних мереж, показником культурного розвитку поколінь в історичних змінах. Тобто оновлення практик поколінь можна визначити як результат впливів нових історичних обставин на старі звичаї, перетворень і пристосувань акторів до "інших" вимог “іншої” культури. Адже “народження” інституту поколінь відбувається поступово, майже непомітно, у заміщенні звичайного незвичайним, у тимчасовому безладі руйнування конструктів правил і традицій, але за домінування ідей, що для представників часу, в означених умовах, відповідають здоровому глузду. Тобто є практично єдино можливими для реалізації в житті i вважаються цілком зрозумілими й очевидними. Отже, зміну соціальних практик, що стають звичками, стереотипами реагування (притаманними поколінню в час його домінування), можна вважати змінами соціальних систем, у яких одна система поступається своєю домінантою іншій системі, що є більш пристосованою до вимог часу. Але система, що залишається на провідних позиціях (віку, адаптивності, фізичних можливостей, оновленого досвіду та ін.), знову і знову буде стикатися 3 наступними змінами, неминучими і природними (Hamilton, p. 84-89).

Цікаво, що траєкторія руху культури зберігає повільність і непомітність у свідомості учасників історичних процесів доти, доки наступні покоління можуть зберігати технології життєзабезпечення за зразками Батьків і Прабатьків. У цей час, коли немає болючої необхідності в деталізованому аналізі і препаруванні, механізми життєустрою залишаються прихованими. Але історичні соціальні зсуви, як “розломи у свідомості”, вносять нові ідеї і нову “мудрість”, необхідну для виживання, а “мудрість, що належить минулому і є продуктом минулого досвіду” (Hamilton, p. 88), відкидають у небуття, до часів вимушеного повернення в умови життя пращурів. Таким чином складний світ переплетених досвідів, символічних систем і смислів (оновлених і тимчасово сталих) утворює заплутане мереживо поколінних соціокультурних взаємодій.

Зазначимо, що соціальний інститут (і саме поколінний), як “жива істота", має “нечіткий” i “недеталізований” образ, лише начерк, але ті життєві практики, що існували довгий час, опрацьовувалися в житті минулих поколінь (були отримані у “спадок”), стають досвідом (тим, що вже було пережито) і потенціалом (ресурсами, що будуть у майбутньому використані, можливо, нащадками). Тому, як пише W. Hamilton, дослідження інституту соціального (і поколінного) “вимагає вивчення історії життя” - соціальних практик, прояву габітусів нових поколінь (Hamilton, p. 88-89).

Такі пошуки причинно-наслідкових зв'язків соціальних явищ у безперервних змінах реальності, розкриття питань взаємопов'язаності ментального прояву та історично базисного були означені P. Bourdieu як необхідність дослідження впливових латентних структур та особливостей реалізації диспозицій на основі життєвого досвіду, в конкретних соціальних полях. У поєднанні структурності соціуму і мисленнєвих конструктів Р. Bourdieu виокремив соціальні обмеження детермінації. Дослідник пов'язав їх з умовами існування акторів і визначив як складну матрицю габітусу: системи диспозицій; продукту соціального світу; генератора стратегій, пристосування до соціальних ситуацій; примусу часу i, водночас, вимоги соціальної гри щодо ведення відносин; принципу, що не обирає дію, а пристосовує до соціальних ситуацій; обумовленого соціально, адаптованого способу життя; системи набутих схем, категорій сприймання та оцінювання, принципів класифікації; генератора практик; ментальної структури; продукту інтеріоризації; образу, 
модельованого соціальними факторами, реалізованого учасниками соціальних відносин (Бурдьё, 1994; 2005).

У нашому дослідженні ментальні конструкти пояснення, інтерпретування поколінних психічних утворень, накопичених у ході взаємодії з культурою інших поколінь, реалізовані в соціальних процесах пізнання, включення акторів у дійсність, будуть окреслені в рамках категорії, запропонованої Р. Bourdieu. А габітус представлено як синтетичний прояв ментальних конструктів, модельованих соціальними факторами, що опосередковують відчуття реальності - "sense of one's place" (відчуття перебування на своєму місті) i “sense of others'place” (відчуття чужого для себе місця) в диспозиціях, стратегіях, практиках, соціальних іграх акторів (Бурдьё, 1994). Адже поколінні габітуси як своєрідні поколінні досвіди у “згорнутому” вигляді є моделлю ресурсів, що проростають у соціокультурних вимірах, задають шляхи виборів, по-перше, у пристосуванні до соціально-історичних умов реалізації потенціалів; по-друге, у гнучкій, своєчасній зміні метрик проявів ієрархій, смислів, динамічності, домінуючого оволодіння і відступу в соціальних зв'язках; i, по-третє, у ментальних рухах презентацій світу поколінних диспозицій. Тому габітус як ментальні конструкти поколінь буде розглянуто також як ментальні схеми отримання, породження, об'єднання, оцінювання, класифікації i використання інформації; диспозиційні рухи вибудовування оновлених форм фігурацій, що приписують або пророкують необхідні форми зв'язків, необхідні (для задоволення потреб) кожному актору у “своїх оптимальних” формах.

При цьому габітус, як ментальний конструкт, означує також продукт спільногрупової психічної діяльності, що реалізується у вибудовуванні поколінного досвіду і смислів. Адже концептуальне змішування ментальних просторів відіграє в житті суспільства фундаментальну роль у побудові смислів життя поколінь (G. Fauconnier, M. Turner), де артикуляція конструкції уявлень та організації знань, умовно незалежних ментальних просторів, їх частковий збіг у природному змішуванні приводить до нових смислів, глобального розуміння i концептуальних стискань, у яких інтерпретування реальності є частковою сукупністю елементів реальності, суб'єктів, когнітивних моделей (Fauconnier, 2003, p. 56-86). Тому в переплетенні ментальних реальностей поколінь знаходять своє місце і збережені базові аспекти минулого, і привнесені знання сучасного в контекстах історичних ситуацій.

Отже, перемішані в соціально-психологічному просторі реальності поколінь Батьків, Прабатьків, з одного боку, набувають нової динаміки, а з другого - у поєднаннях соціальних вимірів зберігають статичними базову культурну основу, способи прояву габітусу і реалізацій диспозицій. Саме це виокремлює питання знаходження зон пересічних стикань досвідів у вибудовуванні нових моделей реальності покоління Дітей, необхідних і актуальних для сучасників у конкретній історичній площині.

\section{Висновки та перспективи подальших досліджень}

1. Розглянуто особливості розгортання динамічного поля співіснування поколінь. Зауважено суттєвість впливів соціокультурних вимірів, форм проявів еспектацій на міжпоколінні психологічні дистанції.

2. 3'ясовано, що поколінні ентелехії, соціальні практики і габітуси набувають свого оформлення, змін, презентацій у контекстах соціальних ситуацій - вибудовують і реалізують загальночасові міжпоколінні еспектаціï.

3. Обгрунтовано використання як категорії відображення поколінних позицій неологізму Арістотеля ентелехія - як комплексного показника прояву соціально-психологічних особливостей, що об'єднує переплетені мінливі імпульси покоління, означує спрямованість до реалізації потенціалів, можливостей, утворення смислового наповнення реальності й реалізується в соціальних позиціях, тобто настановленнях, цілях, уявленнях.

4. Визначено за доцільне соціальні практики покоління, притаманні поколінню в час його домінування, представляти як габітуалізовані дії, що стали звичками, стереотипами реагування, моделями поведінки у вибудовуванні системи міжпоколінних взаємодій.

5. У контексті дослідження представлено поняття (1) поколінного інституту в ракурсі нестатичного феномену, що виконує функції механізму закріплення практик, набутих упродовж поколінного життя; (2) інституалізації форм соціальних взаємодій у ментальній площині як такої, що здійснює встановлення можливих у часовому історичному контексті порядків, формує звичаї i традиції; стабілізує і відтворює дієві моделі відносин, їхні форми в межах “умовних” норм, правил, моралі. 
6. Обгрунтовано використання поняття габітус (1) як синтетичного прояву ментальних конструктів, модельованих соціальними факторами, що опосередковують відчуття реальності в диспозиціях, стратегіях, практиках, соціальних іграх акторів; (2) як ментальних схем отримання, породження, об’єднання, оцінювання, класифікації і використання інформації; (3) як диспозиційних рухів вибудовування оновлених форм фігурацій, що приписують або пророкують необхідні для задоволення потреб форми зв'язків; (4) як породження ментальності, тобто продукт спільнопоколінної психічної діяльності, що реалізується в динамічному вибудовуванні досвіду і смислів.

У подальшому вибудовуванні концепції фігуративних соціокультурних зв'язків поколінь перспективою майбутніх розвідок $є$ розкриття особливостей поколінних зв'язків (фігурації), функціонування поколінних капіталів/ресурсів, необхідних для задоволення інтересів агрегованих акторів.

\section{Список використаних джерел}

Англо-русский словарь по социологии (2011). Habitus, habitualization. Взято из https://sociology_en_ru.academic.ru/6309/habitualization.

Аристотель (1976). Сочинения в четырех томах. Т. 1. Асмус. Москва: Мысль.

Бергер, П., \& Лукман, Т. (1995) Социальное конструирование реальности. Трактат по социологии знания. Москва: Academia-центр, Медиум.

Бурдьё, П. (1994). Начала. Москва: Socio-Logos. Взято из http://bourdieu.name/content/socialnoeprostranstvo-i-simvolicheskaja-vlast.

Бурдьё, П. (2001). Практический смысл. Санкт-Петербург: Алетейя, (“Gallicinium”). Взято из http://gtmarket.ru/laboratory/basis/4783/4794.

Бурдьё,П. (2005). Социальное пространство: поля и практики. Санкт-Петербург: Алетейя (Серия "Gallicinium"). Запада).

Веблен, Т. (1984). Теория праздного класса: монография. Москва: Прогресс (Экономическая мысль

Гидденс, Э. (1994). Социология. Социологические исследования, 2, 129-138. Взято из http://ecsocman.hse.ru/data/540/189/1217/020_Giddens.pdf.

Гидденс, Э. (2005). Социология. Изд. 2-е, полностью перераб. и доп. Москва: Едиториал URSS. Взято из http://yanko.lib.ru/books/sociology/giddens-sociology-ru-a.htm.

Гуссерль, Э. (2004). Кризис европейских наук и трансиендентальная феноменология: Введение 6 феноменологическую философию. Санкт-Петербург: Владимир Даль.

Данченко, В. Краткий очерк западного эзотеризма. В Очерки эзотерической психологии эпохи развитого соииализма. Взято из http://psylib.org.ua/books/danch02/txt01.htm.

Доброхотов, А. Л. (1986). Категория бытия в классической западноевропейской философии. Аристотель. Москва: Изд-во Моск. ун-та. Взято из http://psylib.org.ua/books/dobro01/txt05.htm.

Кнабе, Г. С. (2007) Энтелехия. В Культурология. Энциклопедия. В 2-х т. Т. 2. Москва, р. 1069. Взято из http://bit.ly/2mgOyVu.

Кнабе, Г. С. (1993). Энтелехия культуры. В Материалы к лекииям по общей теории культуры и культуре античного Рима. Москва, pp. 139-156.

Парсонс, Т. (2008). Социальные системы. Вопросы социальной теории. Т. 2, Вып. (2), Москва, c. $38-71$.

Штомпка, П. (2009). В фокусе внимания повседневная жизнь. Новый поворот в социологии. Сочиологические исследования, (8), 3-13.

Штомпка, П. (1996). Социология соуциальных изменений. Москва: Аспект Пресс.

Giddens, А. (1989). Sociology. В Михалева К. Ю., \& Полякова Н. Л. (2012). Концепция социального института в социологической теории. Вестник Московского университета. Серия 18. Социология и политология, 2, 117-132.

Gilles, F. \& Turner, M. (2003). Conceptual blending, form and meaning. Retrieved from http://tecfa.unige.ch/tecfa/maltt/cofor-1/textes/Fauconnier-Turner03.pdf.

Hamilton, W. (1932). Institution. B International Encyclopedia of the Social Sciences. Retrieved from http://home.sogang.ac.kr/sites/kylee/Courses/Lists/b6/Attachments/12

/International\%20Encyclopedia\%20of\%20Social\%20sciences.pdf. 
Rummel, R. J. (1975). Understanding conflict and war: Vol. 1: The Dynamic Psychological Field. Beverly Hills, California: Sage Publications. Retrieved from https://www.hawaii.edu/powerkills/ DPF.CHAP18.HTM\#*.

\section{References}

Anglo-russkiy slovar po sotsiologii [English-Russian Dictionary of Sociology] (2011). Habitus, habitualization. Retrieved from https://sociology_en_ru.academic.ru/6309/habitualization. (in Russian)

Aristotel (1976). Sochineniya v chetyrekh tomakh [Works in four volumes]. Vol. 1. Moscow: Mysl. (in Russian)

Berger, P., \& Lukman, T. (1995). Sotsialnoye konstruirovaniye realnosti [Social Construction of Reality]. Moscow: Academia-tsentr, Medium. (in Russian)

Bourdieu, P. (1994). Nachala [Beginnings]. Moscow: Socio-Logos. Retrieved from http://bourdieu.name/content/socialnoe-prostranstvo-i-simvolicheskaja-vlast. (in Russian)

Bourdieu, P. (2001). Prakticheskiy smysl [Practical sense]. St. Petersburg: Aleteyya (“Gallicinium”). Retrieved from http://gtmarket.ru/laboratory/basis/4783/4794 (in Russian)

Bourdieu, P. (2005). Sotsialnoye prostranstvo: polya $i$ praktiki [Social space: fields and practices]. St. Petersburg: Aleteyya (Seriya "Gallicinium"). (in Russian)

Danchenko, V. Kratkiy ocherk zapadnogo ezoterizma [A brief essay on Western esotericism]. Retrieved from [http://psylib.org.ua/books/danch02/txt01.htm. (in Russian)

Dobrokhotov, A. L. (1986). Kategoriya bytiya v klassicheskoy zapadnoyevropeyskoy filosofii. Aristotel [Category of being in classical Western European philosophy. Aristotle]. Moscow: Izdatelstvo Moskovskogo universiteta. Retrieved from http://psylib.org.ua/books/dobro01/txt05.htm. (in Russian)

Giddens, A. (1994). Sotsiologiya [Sociology]. Sociologicheskiye issledovaniya, 2, 129-138. Retrieved from http://ecsocman.hse.ru/data/540/189/1217/020_Giddens.pdf. (in Russian)

Giddens, A. (2005). Sotsiologiya [Sociology]. Moscow: Editorial URSS. Retrieved from http://yanko.lib.ru/books/sociology/giddens-sociology-ru-a.htm (in Russian)

Giddens, A. (1989). Sociology. In Mikhaleva, K. Yu., Polyakova, N. L. (2012). Kontseptsiya sotsialnogo instituta v sotsiologicheskoy teorii [The Concept of Social Institute in Sociological Theory]. Vestnik Moskovskogo universiteta. Seriya 18. Sotsiologiya i politologiya, 2, 117-132. (in Russian)

Gilles, F., \& Turner, M. (2003). Conceptual blending, form and meaning. Retrieved from http://tecfa.unige.ch/tecfa/maltt/cofor-1/textes/Fauconnier-Turner03.pdf. (in English)

Hamilton, W. (1932). Institution. In International Encyclopedia of the Social Sciences. Retrieved from http://home.sogang.ac.kr/sites/kylee/Courses/Lists/b6/Attachments/12

/International\%20Encyclopedia\%20of\%20Social\%20sciences.pdf.

Husserl, E. (2004). Krizis yevropeyskikh nauk $i$ transtsendentalnaya fenomenologiya: Vvedeniye $v$ fenomenologicheskuyu filosofiyu [Crisis of European Sciences and Transcendental Phenomenology: Introduction to Phenomenological Philosophy]. St. Petersburg: Vladimir Dal. (in Russian)

Knabe, G. S. (1993). Entelekhiya kultury [Entelechy of culture]. In Materialy k lektsiyam po obshohey teorii kultury i kulture antichnogo Rima. Moscow, pp. 139-156. (in Russian)

Knabe, G. S. (2007). Entelekhiya. In Kulturologiya. Entsiklopediya. In 2 Vol., Vol. 2. [Entelechy. Culturology. Encyclopedia]. In 2 Vol., Vol. 2. Retrieved from http://bit.ly/2mgOyVu. (in Russian) Russian)

Parsons, T. (2008). Sotsialnyye sistemy [Social systems]. Voprosy sotsialnoy teorii, vol. 2, 1(2), 38-71. (in

Rummel, R. J. (1975). Understanding conflict and war: Vol. 1: The Dynamic Psychological Field. Beverly Hills, California: Sage Publications. Retrieved from https://www.hawaii.edu/powerkills/ DPF.CHAP18.HTM\#*. (in English).

Sztompka, P. (2009). V fokuse vnimaniya povsednevnaya zhizn. Novyy povorot v sotsiologii [The focus of attention is everyday life. New turn in sociology]. Sotsiologicheskiye issledovaniya, (8), 3-13. (in Russian)

Sztompka, P. (1996). Sotsiologiya sotsialnykh ismeneniy. [The Sociology of Social Change]. (in Russian)

Veblen, T. (1984). Teoriya prazdnogo klassa [Theory of the Leisure Class]. Moscow: Progress (Ekonomicheskaya mysl Zapada). (in Russian) 